\title{
CHEMICAL COMPOSITIONS AND ANTIOXIDANT AND ANTIMICROBIAL ACTIVITIES OF PROPOLIS PRODUCED BY Frieseomelitta longipes AND Apis mellifera BEES
}

Edineide Cristina A. de Souza ${ }^{a}$, Etyene Janyne G. da Silva ${ }^{a}$, Hayron Kalil C. Cordeiro ${ }^{b}$, Nauara M. Lage Filho ${ }^{\text {, }}$, Felipe M. A. da Silva ${ }^{c}$, Diany Lucy S. dos Reis ${ }^{d}$, Carla Porto ${ }^{d}$, Eduardo J. Pilau ${ }^{d}$, Luiz Antonio M. A. da Costa ${ }^{a}$, Afonso D. L. de Souza $^{c}$, Cristiano Menezes ${ }^{\mathrm{e}}$ and Adriana Flach ${ }^{\mathrm{a}, * a}$

aDepartamento de Química, Universidade Federal de Roraima, 69310-000, Boa Vista - RR, Brasil

bUniversidade Federal Rural da Amazônia, 66075-110 Belém - PA, Brasil

'Departamento de Química, Universidade Federal da Amazônia, 69077-000, Manaus - AM, Brasil

'Departamento de Química, Universidade Estadual de Maringá, 87020-900, Maringá - PR, Brasil

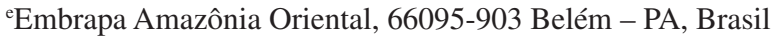

Recebido em 24/08/2017, aceito em 15/01/2018, web 28/02/2018

\begin{abstract}
In this study, we investigated the chemical compositions and antioxidant and antimicrobial activities of propolis produced by the stingless bee Frieseomelitta longipes and the honeybee Apis mellifera collected from colonies in North Brazil. In terms of volatile composition, both mono- and sesquiterpenes were detected in the propolis of $F$. longipes while only sesquiterpenes were detected in that of A. mellifera. Out of 50 volatiles identified in all samples, 26 were found exclusively in $F$. longipes propolis and 8 were found exclusively in A. mellifera propolis. The chemical profiles of the propolis extracts were determined by atmospheric pressure chemical ionization-mass spectrometry and liquid chromatography-electrospray ionization-tandem mass spectrometry allowed to identify several prenylated benzophenones. A. mellifera extracts exhibited major antioxidant activity as assessed by the 2,2-diphenyl-1picrylhydrazyl method and all extracts exhibited antioxidant activity as assessed by the $\beta$-carotene/linoleic acid method. The ethanolic extracts of the propolis showed promisor activity against all tested microorganisms.
\end{abstract}

Keywords: volatiles; phenolics; terpenes; stingless bee; honeybee.

\section{INTRODUCTION}

Since ancient times, propolis has been used as an alternative medicine owing to its biological action. Besides its antimicrobial activity, it has several therapeutic properties, such as antitumor, antioxidative, and anti-inflammatory activities. ${ }^{1}$ Propolis has become popular as an alternative medicine and is a constituent of several cosmetics and health products. Many studies have been conducted to elucidate the chemical compositions and biological activities of propolis from different regions of the world. ${ }^{2,3}$

Propolis is a resinous material found in colonies of many eusocial bee species. It is derived from plant resins collected by foragers and used to close gaps in hives, trapping the bodies of small invaders. It works as a physical barrier against natural enemies and also as a biochemical weapon against pathogenic or opportunistic microbes. Recent findings have also revealed its important role in colony immunity. ${ }^{4}$

The propolis used worldwide is harvested from the same bee species, Apis mellifera, also known as honeybees. Although from the same bee, the product is not standard because its composition can differ depending on the plants of the region where, and the season when, it is produced. In Brazil, for example, there are two well-known types of propolis: green propolis, produced in Southeast and Central Brazil from Baccharis dracunculifolia, a plant of the Asteraceae family, and red propolis, produced in the littoral regions of Northeast Brazil from Dalbergia ecastaphyllum, a plant of the Leguminosae family., 2,56

The chemical composition of propolis can also differ depending on the bee species. Several other eusocial bees can be managed in hives, such as those of the Meliponini tribe (also known as stingless bees), which produce pure propolis with great potential for commercial use. Stingless bees occur in all tropical and subtropical areas of the globe and

*e-mail: aflach@gmail.com consist of more than 500 different species. Unlike honeybees, stingless bees mix propolis with wax to produce a building material, known as cerumen, which is used to construct all the structures in their nests, such as brood combs, entrances, and food pots. Recent studies have found that propolis from stingless bees has interesting characteristics and sometimes stronger biological activities than propolis from honeybees..$^{8-11}$ However, its commercial use remains limited because little is known about its composition or whether its properties make propolis production from these species economically viable.

Propolis contains volatile and fixed compounds. The volatile fraction corresponds to what are also called essential oils and contains mono- and sesquiterpenes, as well as alkanes and various aromatic compounds. ${ }^{9,12,13}$ The fixed compounds in propolis comprise triterpenoids, flavonoids, lignans, phenolic esters of caffeic and coumaric acids, diterpenes, and prenylated benzophenones, among others. $^{2,3}$

In the present study, we aimed to investigate whether the propolis produced by different bee species in the same area and at the same time are different.

We hypothesized that each bee species would use different resin sources and have specific processing methods, therefore producing unique propolis. To test this hypothesis, we compared the chemical compositions of propolis produced by two bee species, Apis mellifera (Apidae: Apini) and Frieseomelitta longipes (Hymenoptera: Apidae: Meliponini), located in the same area of the Amazon region of Brazil over the same time period.

\section{MATERIALS AND METHODS}

\section{Propolis collection}

Propolis samples were collected from colonies in the apiary of 
Embrapa Eastern Amazon, in the city of Belém, Brazil. Three colonies of $F$. longipes and one colony of A. mellifera were used. The colonies of the stingless bees and A. mellifera were separated by 50 meters. The surrounding area is predominantly composed of native secondary forest of the Amazonian ecosystem, but there are also urban areas and experimental Embrapa fields close to the apiary. To stimulate the production of propolis, two 2-cm-wide louvers were made in the side of the hives between the cover and the colony nest and sealed with adhesive transparent tape. Propolis was collected 15 days after the introduction of the louvers. Three samples of propolis collected from F. longipes colonies (FL-1, FL-2, and FL-3) and one collected from the A. mellifera colony (AM) were sent to the Laboratory of Biotechnology and Fine Chemistry at the Federal University of Roraima for analysis.

\section{Volatiles extraction}

The propolis samples were chilled and powdered using a pestle and mortar. Portions of 15 to $20 \mathrm{~g}$ were subjected to hydrodistillation for $3 \mathrm{~h}$ in a modified Clevenger apparatus and the essential oil collected was dried over anhydrous sodium sulfate. The yield from the extraction was determined by the proportional relationship between the weight of the propolis samples and the weight of the obtained oil.

\section{Volatile compound analysis by gas chromatography-mass spectrometry (GC-MS)}

A Shimadzu gas chromatograph (model GC-2010) coupled to a mass spectrometer from the same manufacturer (model QP2010 Plus) was used for the analysis of volatile compounds. Separation was performed using a fused silica capillary column (RTX-5MS, $30 \mathrm{~m} \times 0.25 \mathrm{~mm} \times 0.25 \mu \mathrm{m})$. A $1 \mu \mathrm{L}$ aliquot of a $15 \mathrm{mg} \mathrm{mL}^{-1}$ ethyl acetate solution of the oil was injected into the chromatograph. The injector temperature was $220^{\circ} \mathrm{C}$, the interface temperature was $280{ }^{\circ} \mathrm{C}$, and the column temperature was programmed to increase from $60{ }^{\circ} \mathrm{C}$ at $3{ }^{\circ} \mathrm{C} \mathrm{min}^{-1}$ to $280{ }^{\circ} \mathrm{C}$. Helium was used as the carrier gas at a constant flow rate of $1.02 \mathrm{~mL} \mathrm{~min}^{-1}$. Mass spectra were acquired in the $m / z$ range $40-600$ using electron ionization with an ionization power of $70 \mathrm{eV}$ and the ion source at $260{ }^{\circ} \mathrm{C}$.

\section{Volatile constituent identification}

The compositions of the essential oils were determined by comparing the values of their retention indexes with those obtained for a homologous series of $n$-alkanes $\left(\mathrm{C}_{7}-\mathrm{C}_{30}\right)$ under the same conditions, according to the method of Van den Dool and Kratz. ${ }^{14}$ Later, the experimental mass spectra were verified by comparison with those in the Wiley 8 and FFNSC 1.2 digital libraries and with data from existing literature. ${ }^{15}$

\section{Extract preparation}

Powdered propolis samples (4.10-34.29 g) were subjected to extraction at $25^{\circ} \mathrm{C}$ three times using $250 \mathrm{~mL}$ absolute ethanol $(99.5 \%)$ over a period of $24 \mathrm{~h}$. The extracts were combined, concentrated on a rotary evaporator, and stored in a desiccator at reduced pressure.

\section{Chemical ionization at atmospheric pressure analysis}

The mass spectra were acquired using an ion-trap type spectrometer (Thermo-LCQ fleet) equipped with an atmospheric pressure chemical ionization (APCI) source programmed to operate in positive and negative acquisition modes. The information was recorded using acquisition continuum mode using LCQ Fleet Tune. The monitored track was $m / z, 100-1000$. Stock solutions were diluted at $20 \mathrm{ppm}$ in HPLC-grade methanol and applied by direct insertion from a 5- $\mu \mathrm{L}$ loop using a pump syringe as a transport vehicle. The operational conditions were: APCI(-): discharge voltage, $3 \mathrm{kV}$; vaporizer temp, $300{ }^{\circ} \mathrm{C}$; IRS gas, 30 arbs; auxiliary gas, 10 arbs; sweep gas, $0 \mathrm{arb}$; capillary temp, $200{ }^{\circ} \mathrm{C}$; capillary voltage, $-40 \mathrm{~V}$;

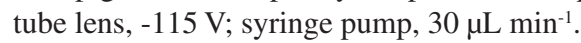

\section{Liquid chromatography-electrospray ionization tandem mass spectrometry (LC-ESI-MS/MS) analysis}

Propolis extracts were reconstituted in $500 \mu \mathrm{L}$ of methanol, and $50 \mu \mathrm{L}$ of this extract was diluted in $450 \mu \mathrm{L}$ of the same solvent and analyzed using by Ultra High Performance Liquid Chromatography (Shimadzu, Nexera X2) coupled to a quadrupole time-of-flight mass spectrometer (Bruker, Impact II UHR-QTOF) controlled by the Otof Control and Hystar software packages (Bruker Daltonics) and equipped with an electrospray source operating in negative ionization mode. The parameters used for ESI(-) mode were: capillary voltage, 3.0 KV; nebulizer gas pressure, 4.0 Bar; dry heater temperature $220^{\circ} \mathrm{C}$. Full-scan MS spectra $(\mathrm{m} / \mathrm{z}, 100-1300)$ were acquired, and the ions of interest were selected by auto MS/MS scan fragmentation. Chromatographic separation was performed with a gradient mixture of solvents $\mathrm{A}\left(\mathrm{H}_{2} \mathrm{O} / 0.1 \%\right.$ formic acid, $\left.v / v\right)$ and $\mathrm{B}$ (methanol) using a $\mathrm{C}_{18}$ column (Waters Acquity UPLC® $\mathrm{CSHH}^{\mathrm{TM}} 1.7 \mu \mathrm{m}, 2.1 \times 100 \mathrm{~mm}$ ). The column was maintained at $40{ }^{\circ} \mathrm{C}$, the flow rate was $0.2 \mathrm{~mL} \mathrm{~min}^{-1}$, and the sample injection volume was $2 \mu \mathrm{L}$. The separations ran for 20 min using the program: 0-1 min: $40 \% \mathrm{~B}, 1-7 \mathrm{~min}$ : $90 \% \mathrm{~B}$, 7-13 min: $97 \% \mathrm{~B}$, followed by an isocratic elution in the period from 13 to 16 min at $97 \% \mathrm{~B}$, and finally $16-18 \mathrm{~min} 40 \% \mathrm{~B}$, keeping $40 \%$ until $20 \mathrm{~min}$ to re-equilibrate the column prior to another run. Sodium formiate solution was injected as calibrant at the start of each chromatographic run.

\section{2,2-Diphenyl-1-picryl-hydrazyl (DPPH) radical-scavenging activity analysis}

The analyses were performed according to the methodology described by Mensor et al. ${ }^{16}$ with some modifications. For the extracts of $F$. longipes propolis, a $1 \mathrm{mg} \mathrm{mL}^{-1}$ sample was used, and for A. mellifera propolis, a $0.1 \mathrm{mg} \mathrm{mL}^{-1}$ sample was used. Different sized aliquots of these solutions were withdrawn (for $F$. longipes, 20, 30, 40, 50, 60, and $70 \mu \mathrm{L}$, and for A. mellifera, 25, 50, 75, 100, 125, and $150 \mu \mathrm{L})$, followed by addition of $1.5 \mathrm{~mL} \mathrm{DPPH}\left(1 \mathrm{mmol} \mathrm{L}^{-1}\right)$. A control solution consisting of $1.5 \mathrm{~mL}$ of a solution of DPPH and methanol was also prepared. The blank was formed by the same aliquots of samples and methanol. The determinations were performed using a UV-Vis spectrophotometer (Shimadzu UV-mini model 1240). The percentage uptake of the DPPH radicals was used to calculate percentage antioxidant activity $(\mathrm{AA} \%) . \mathrm{IC}_{50}$ values were determined using linear regression analysis.

\section{Antioxidant activity analysis using the $\beta$-carotene/linoleic acid system}

For the oxidation of samples, we used the methodology described by Emmos et al., ${ }^{17}$ whereby $50 \mu \mathrm{L}$ of a $\beta$-carotene solution ( $1 \mathrm{mg} \mathrm{mL}^{-1}$ ), $40 \mu \mathrm{L}$ of linoleic acid, and $265 \mu \mathrm{L}$ of Tween 80 were mixed and solubilized in $1 \mathrm{~mL}$ of chloroform. The chloroform was removed with nitrogen $\left(\mathrm{N}_{2}\right)$ before the residue was then dissolved in aerated water $(150 \mathrm{~mL})$. A $5 \mathrm{~mL}$ aliquot of the emulsion was added to $100 \mu \mathrm{L}$ of the propolis extracts $\left(1 \mathrm{mg} \mathrm{mL}^{-1}\right)$, after which 
the mixture was a water bath at $40{ }^{\circ} \mathrm{C}$. Oxidation was monitored in a spectrophotometer at $470 \mathrm{~nm}$. A $\beta$-carotene/linoleic acid emulsion without antioxidant was used for control samples, and a $1 \mathrm{mg} \mathrm{mL}^{-1}$ solution of 2,6-tert-butyl-1-hydroxy-toluene (BHT) was used as a positive control. The antioxidant activity (AA\%) was expressed as the percentage of inhibition compared with that of the control after $120 \mathrm{~min}$

\section{Antimicrobial activity}

The gram-positive bacteria Bacillus cereus INCQS 00003 (ATCC 11778) and Staphylococcus aureus INCQS 0057 (ATCC 43300), the gram-negative bacteria Pseudomonas aeruginosa INCQS 00025 (ATCC 15442) and Escherichia coli INCQS 00051 (ATCC 13863), and the yeasts Candida albicans (ATCC 90028) and Candida tropicalis (ATCC 28707) were utilized for antimicrobial tests. The strains were supplied by the Coleção de Microrganismos de Referência em Vigilância Sanitária (CMRVS, FIOCRUZ-INCQS, Rio de Janeiro, RJ, Brazil). The bacteria were cultivated in brain-heart infusion medium (BHI) at $36 \pm 1{ }^{\circ} \mathrm{C}$ for $24 \mathrm{~h}$ and the yeasts were cultivated in Sabouraud agar at $36 \pm 1{ }^{\circ} \mathrm{C}$ for $36 \mathrm{~h}$.

The cultures were adjusted to $0.5 \mathrm{McF}$ arland $\left(1 \times 10^{8}\right)$ standard turbidity scale equivalents $\left(10^{5} \mathrm{CFU} \mathrm{mL} \mathrm{mL}^{-1}\right)$, then a dilution $(1: 10)$ was

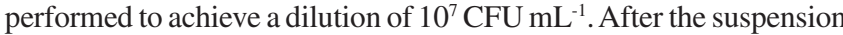
was inoculated into the broth, the final bacterial concentration of the test was $10^{5} \mathrm{CFU} \mathrm{mL} \mathrm{mL}^{-1}$, as recommended by CLSI (2012). The minimum inhibitory concentration values (MICs) of the ethanolic extracts were determined with 96 -well plates as per a method established by the Clinical and Laboratory Standards Institute (CLSI). ${ }^{18}$ The negative control was $80 \%$ ethanol and the positive controls were ampicillin and fluconazole. The extract concentrations tested were $1000,500,250,125,62.5,31.3,15.6$, and $7.8 \mu \mathrm{g} \mathrm{mL}^{-1}$ and 2,3,5-triphenyl tetrazolium chloride (TCC) was used to assess the viability of the microorganisms.

\section{RESULTS AND DISCUSSION}

\section{Volatiles}

The relative abundances of essential oils in the $F$. longipes propolis varied between the colonies sampled. FL-1 had an essential oil percentage of $0.07 \%$, while FL-2 and FL-3 had much higher values of 0.47 and $0.78 \%$, respectively. In contrast, A. mellifera contains only $0.12 \%$ essential oils.

The essential oil constituents of propolis from $F$. longipes and A. mellifera are listed in Table 1. In the propolis of $F$. longipes, around 40 compounds were identified as mono- and sesquiterpenes. There is much less variety in the compounds found for in A. mellifera propolis, which comprises exclusively sesquiterpenes.

Six monoterpenes were identified in F. longipes. Sample FL-1 presented lower concentration of monoterpenes (1.40\%) compared to those of FL-2 and FL-3 (14.58 and $10.74 \%$, respectively). The most abundant monoterpene was (Z)-ocimene (7.43\%, in FL-2).

Among the sesquiterpenes, $\beta$-caryophyllene presented the highest percentages in all the processed samples (19.6\% in FL-1, $20.99 \%$ in FL-2, 34.52\% in FL-3 and $31.42 \%$ in AM). The sesquiterpenes that presented contents of $>5 \%$ in A. mellifera were $\alpha$-copaene $(9.43 \%)$, cyperene $(6.24 \%), \alpha$-humulene $(7.06 \%), \gamma$-gurjunene $(5.55 \%)$, $\beta$-bisabolene $(5.53 \%)$, and $\delta$-cadinene $(8.61 \%)$. Of these, cyperene and $\gamma$-gurjunene were not detected in $F$. longipes propolis. F. longipes propolis presented significant percentages of $\alpha$-copaene $(3.87-5.99 \%)$, $\alpha$-humulene (4.38-6.16\%), germacrene D (2.98-6.95\%), $\delta$-cadinene
(6.95-7.45\%), and $\gamma$-cadinene (3.38-5.46\%). Of these, germacrene $\mathrm{D}$ was not detected in A. mellifera propolis.

Patricio et al. identified components in the tibia of three Frieseomelitta species collected in different places. ${ }^{19}$ When comparing the data obtained in their study to that obtained in the current study for the propolis of $F$. longipes, it is confirmed that no component is present in all the samples analyzed for this genus of bees, demonstrating that there is no uniformity in their compositions. $\alpha$-phellandrene in $F$. longipes, $F$. silvestrii, and $F$. s. languida, and $\alpha$-cubebene and $\alpha$-copaene in $F$. longipes, $F$. silvestrii, and $F$. varia were detected. Comparing $F$. longipes and F. silvestrii, eight common components were identified: $\alpha$-phellandrene, $\alpha$-cubebene, $\alpha$-copaene, $\beta$-caryophyllene, $\gamma$-muurolene, $\alpha$-muurolene, $\gamma$-cadinene, and $\delta$-cadinene. When $F$. longipes was compared with $F$. s. languida, only one component was identified in both. In a comparison between $F$. longipes and $F$. varia, six common components were identified: $\alpha$-cubebene, $\gamma$-yalangene, $\alpha$-copaene, $\alpha$-gurjunene, E- $\beta$-farnesene, and germacrene $\mathrm{D}$.

There are far fewer studies on the volatile compounds from stingless bees compared to those on the volatile compounds from honey bees. Studies performed with the propolis of A. mellifera and Melipona beecheii obtained in Yucatan, Mexico and extracted with a Likens-Nickerson micro-apparatus identified similar compositions with some qualitative differences. Some compounds were only present in the propolis of A. mellifera and others in that of $M$. beecheii. The authors concluded that the behavior of these two bee species must be different. ${ }^{9}$

Leonhardt et al. showed that the resin from certain tree species did not attract bees, although these species produced large amounts of resin and were often located close to trees from which bees collected resin. ${ }^{20,21}$ Leonhardt et al showed that Borneo stingless bees use olfactory cues to find trees from which to collect resins. Specifically, they use mono- and sesquiterpenes to localize and recognize the source of resins. ${ }^{22}$ In the current study, different components were found between the propolis of $F$. longipes and A. mellifera, even though they are exposed to the same flora in the same period. Thus, they must have different preferences regarding the collection of resins.

\section{Chemical profiles of the extracts by APCI-MS}

Figure 1 shows profiles of the propolis extracts obtained by direct injection of samples from honeybees and stingless bees in negative ion mode.

The chemical profile of propolis from $F$. longipes showed greater variety of compounds compared to that of A. mellifera. However there were common ions in all samples, as is the case for $\mathrm{m} / \mathrm{z}, 109$, 533, 601, and 669. FL-1 and FL-2 exhibit very similar profiles, although FL-3 presents the same ions. Ishida et al. ${ }^{23}$ in studies with propolis samples from A. mellifera of Amazonia, identified the polyprenylated benzophenones 7-epi-nemorosone $(\mathrm{m} / \mathrm{z}, 501)$ and xanthochymol $(\mathrm{m} / \mathrm{z}, 601)$ as the main constituents. These compounds have already been isolated from species of the family Clusiaceae. ${ }^{24,25}$ The ion at $\mathrm{m} / \mathrm{z}, 669$ has been previously identified in the red propolis of Alagoas as a mixture of the isomers guttiferone $\mathrm{C}$ and $\mathrm{D}$ by Mendonça et al. ${ }^{26}$ confirming the predominance of benzophenones in propolis. In terms of the propolis of stingless bees, mainly of the genus Frieseomelitta, there are little data relating to the composition. However, the existing data confirm the relationship of propolis with floral resins of Clusia. Using HPLC analysis TomásBarberán et al. identified prenylated benzophenones in the propolis of Frieseomelitta varia, Melipona favosa, Melipona compressipes, and Scaptotrigona depilis from Venezuela, and verified that Clusia was the resin source. ${ }^{27}$ 
Table 1. Volatile constituents of F. longipes and A. mellifera propolis

\begin{tabular}{|c|c|c|c|c|c|c|}
\hline \multirow{2}{*}{ CONSTITUENTS } & \multirow{2}{*}{$\mathrm{IR}_{\mathrm{L}}$} & \multirow{2}{*}{$\mathrm{IR}_{\mathrm{C}}$} & FL-1 & FL-2 & FL-3 & \multirow{2}{*}{$\mathrm{AM}$} \\
\hline & & & \multicolumn{3}{|c|}{ Area $(\%)$} & \\
\hline \multicolumn{7}{|l|}{ MONOTERPENES } \\
\hline$\alpha$-Phellandrene & 1003 & 1008 & ND & 0.20 & $\mathrm{t}$ & ND \\
\hline Pseudolimonene & 1004 & 1001 & $\mathrm{t}$ & 3.87 & 2.13 & ND \\
\hline$\beta$-Phellandrene & 1030 & 1020 & 0.55 & 0.08 & 3.34 & ND \\
\hline (Z)- $\beta$-Ocimene & 1037 & 1039 & 0.85 & 7.43 & 3.23 & ND \\
\hline Unknown 1 & - & 1049 & ND & 2.57 & 1.86 & ND \\
\hline Camphor & 1146 & 1144 & $\mathrm{t}$ & 0.43 & 0.15 & ND \\
\hline \multicolumn{7}{|l|}{ SESQUITERPENES } \\
\hline$\alpha$-Cubebene & 1351 & 1350 & 3.21 & 1.89 & 1.42 & 0.39 \\
\hline$\alpha$-Ylangene & 1375 & 1372 & 0.30 & 0.26 & 0.12 & 0.28 \\
\hline$\alpha$-Copaene & 1377 & 1376 & 5.99 & 4.32 & 3.87 & 9.43 \\
\hline$\beta$-Bourbonene & 1388 & 1385 & 1.86 & 0.84 & 0.21 & ND \\
\hline$\beta$-Cubebene & 1388 & 1391 & 1.20 & 0.68 & 0.16 & ND \\
\hline$\beta$-Elemene & 1391 & 1393 & 0.48 & 0.22 & $\mathrm{t}$ & ND \\
\hline Iso-Italicene & 1402 & 1396 & 0.37 & 0.22 & 0.14 & ND \\
\hline Cyperene & 1399 & 1398 & ND & ND & ND & 6.24 \\
\hline$\beta$-Longipinene & 1401 & 1400 & 1.43 & 1.55 & 1.49 & ND \\
\hline$\alpha$-Gurjunene & 1410 & 1410 & 1.10 & 1.22 & 0.33 & 1.09 \\
\hline$\alpha$-cis-Bergamotene & 1413 & 1416 & 2.58 & 1.43 & 0.90 & $\mathrm{ND}$ \\
\hline$\beta$-Caryophyllene & 1419 & 1420 & 19.60 & 20.99 & 34.52 & 31.42 \\
\hline$\beta$-Copaene & 1432 & 1430 & 1.35 & 1.02 & 1.00 & ND \\
\hline$\beta$-trans-Bergamotene & 1435 & 1436 & 4.32 & 4.13 & 3.43 & 2.95 \\
\hline$\alpha$-Guaiene & 1440 & 1439 & 0.58 & 0.45 & 0.43 & ND \\
\hline Aromadendrene & 1441 & 1444 & 0.46 & 0.35 & 0.11 & 1.48 \\
\hline$\alpha$-Himachalene & 1451 & 1449 & 0.57 & 0.45 & 0.21 & 0.35 \\
\hline$\alpha$-Humulene & 1455 & 1454 & 4.50 & 4.38 & 6.16 & 7.06 \\
\hline$E$ - $\beta$-Farnesene & 1457 & 1458 & 1.81 & 1.44 & 0.65 & 4.22 \\
\hline 9-epi-(E)-Caryophyllene & 1466 & 1461 & 0.48 & 0.42 & 0.26 & ND \\
\hline allo-Aromadendrene & 1460 & 1461 & ND & ND & ND & 0.51 \\
\hline cis Muurola-4(14),5-diene & 1467 & 1463 & 0.45 & 0.37 & 0.51 & ND \\
\hline trans Cadina-1(6),4-diene & 1477 & 1474 & ND & ND & ND & 0.92 \\
\hline$\gamma$-Gurjunene & 1477 & 1476 & ND & ND & ND & 5.55 \\
\hline$\gamma$-muurolene & 1480 & 1477 & 3.06 & 2.41 & 3.81 & 0.58 \\
\hline Germacrene D & 1485 & 1481 & 6.95 & 4.37 & 2.98 & ND \\
\hline$\beta$-Chamigrene & 1478 & 1484 & 4.55 & 1.30 & 1.52 & ND \\
\hline$\alpha$-Curcumene & 1481 & 1483 & ND & ND & ND & 0.38 \\
\hline Unknown 2 & - & 1485 & ND & 1.96 & 2.21 & ND \\
\hline$\beta$-Selinene & 1490 & 1486 & ND & ND & ND & 3.22 \\
\hline Unknown 3 & - & 1488 & 1.80 & ND & ND & ND \\
\hline cis $\beta$-Guaiene cis & 1493 & 1491 & ND & ND & ND & 0.29 \\
\hline$\gamma$-Amorphene & 1493 & 1492 & 0.47 & 0.52 & 0.36 & 4.40 \\
\hline Valencene & 1496 & 1495 & 2.06 & 1.52 & 3.25 & ND \\
\hline Bicyclogermacrene & 1500 & 1497 & 1.75 & 1.13 & ND & ND \\
\hline$\alpha$-Muurolene & 1501 & 1501 & 0.80 & 0.47 & 0.63 & 0.82 \\
\hline$\beta$-Bisabolene & 1506 & 1509 & 4.03 & 1.57 & 2.37 & 5.53 \\
\hline$\gamma$-Cadinene & 1514 & 1515 & 7.10 & 6.95 & 7.45 & 3.33 \\
\hline$\delta$-Cadinene & 1523 & 1524 & 4.05 & 3.38 & 5.46 & 8.61 \\
\hline$(E)$ - $\gamma$-Bisabolene & 1531 & 1533 & 1.38 & 1.52 & 0.94 & ND \\
\hline trans Cadina-1(2),4-diene & 1535 & 1532 & ND & ND & ND & 0.60 \\
\hline$\alpha$-Cadinene & 1539 & 1538 & 0.45 & $\mathrm{t}$ & 0.23 & ND \\
\hline Germacrene B & 1561 & 1557 & 4.33 & 1.61 & 1.01 & ND \\
\hline Caryophyllene oxide & 1583 & 1583 & 0.54 & 0.51 & 0.43 & 0.35 \\
\hline 1,10-di-epi-cubenol & 1619 & 1616 & 0.40 & 0.40 & 0.20 & ND \\
\hline
\end{tabular}

Legend: $\mathrm{IR}_{\mathrm{L}}$ : literature retention index; $\mathrm{IR}_{\mathrm{C}}$ : calculated retention index; t: trace; ND: not detected. Unknown $1=$ MS data: $43(100 \%), 55(40 \%), 71(60 \%)$, $81(95 \%), 93(80 \%), 108(65 \%), 139(55 \%), 154(40 \%)$. Unknown $2=$ MS data: 41(51\%), 55(25\%), 69(100\%), 105(30\%), 120(35\%), $133(45 \%), 161(35 \%)$. Unknown 3 = MS data: 41(50\%), 55(53\%), 67(40\%), 79(80\%), 91(95\%), 93(100\%), 119(80\%), 121(45\%), 147(45\%), 161(95\%), $189(20 \%), 204(15 \%)$. 


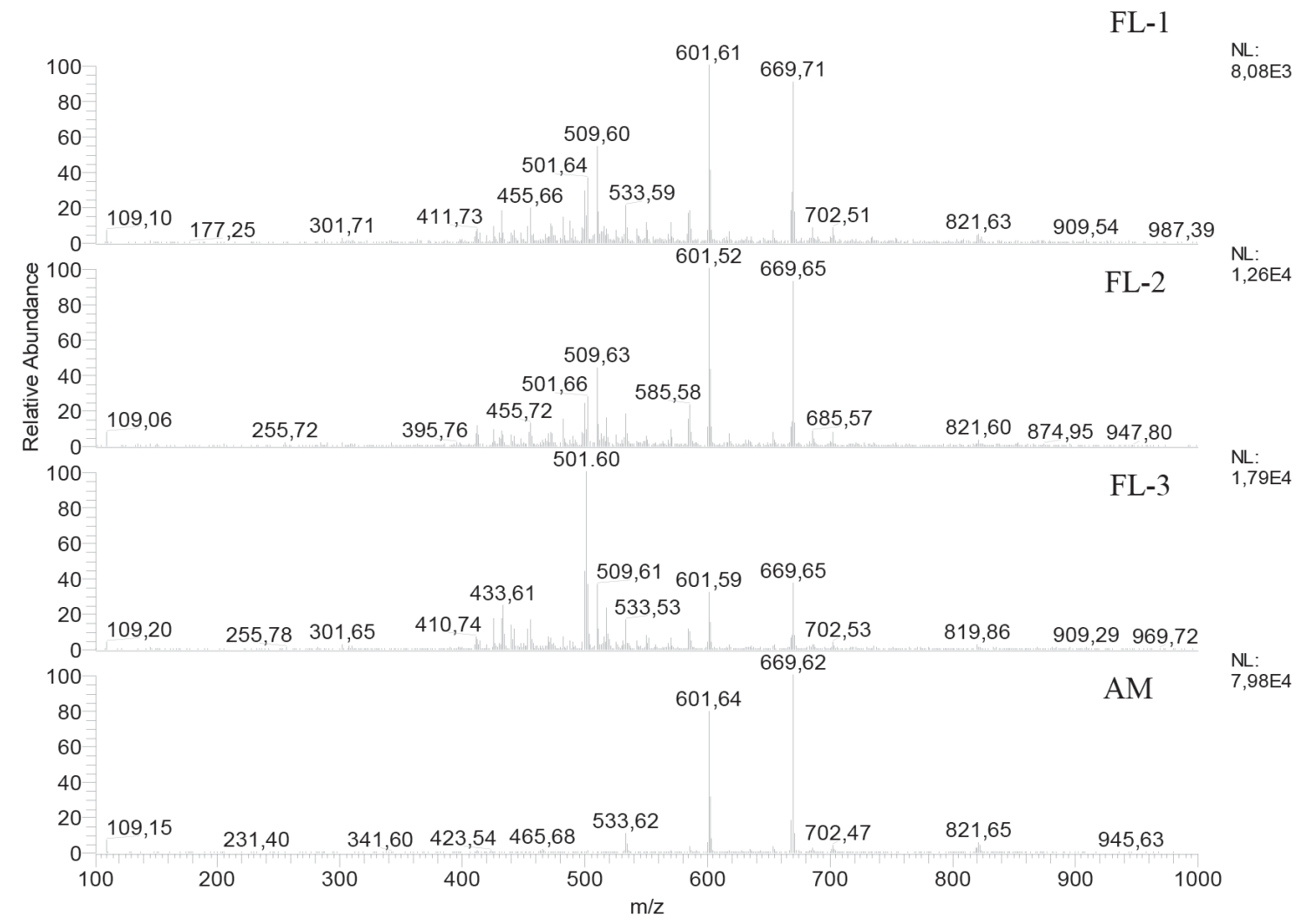

Figure 1. APCI-MS fingerprints of F. longipes and A. mellifera propolis extracts in negative ion mode

\section{LC-ESI-MS/MS analysis}

The LC-ESI-MS/MS analyses were performed in a negative ionization mode to obtain more information about the chemical compositions of the propolis displayed on APCI-MS fingerprint. Ions with $\mathrm{m} / \mathrm{z}$ 451, 501, 533, 601, and 669 were fragmented, and their fragmentation profiles were compared with data described in the literature. ${ }^{23-26}$ This evidence suggests the presence of benzophenones derivatives in all propolis samples (Table 2).

In the sample FL-1, a peak with retention time (RT) $11.65 \mathrm{~min}$

Table 2. Compounds detected in the propolis samples using LC-ESI-MS/MS in negative ion mode.

\begin{tabular}{|c|c|c|c|c|c|c|c|}
\hline Peak & $\begin{array}{l}\text { Retention } \\
\text { Time (min) }\end{array}$ & Sample & Putative Identification & $\begin{array}{l}\text { Molecular } \\
\text { Weight }\end{array}$ & $\begin{array}{c}\text { Precursor Ion } \\
(\mathrm{m} / \mathrm{z})\end{array}$ & $\begin{array}{l}\text { Errorn } \\
(\mathrm{ppm})\end{array}$ & Fragment Ions \\
\hline 1 & 11.65 & $\begin{array}{l}\text { FL-1,FL-2, } \\
\text { FL3, AM }\end{array}$ & 7- epi-Nemorosone & $\mathrm{C}_{33} \mathrm{H}_{42} \mathrm{O}_{4}$ & 501.3002 & 0.59 & $\begin{array}{c}432.2296\left[\mathrm{M}-\mathrm{H}-\mathrm{C}_{5} \mathrm{H}_{9}\right]^{-}, \\
417.2064\left[\mathrm{M}-\mathrm{H}-\mathrm{C}_{5} \mathrm{H}_{9}-\mathrm{CH}_{3}\right]^{\prime}, \\
363.1586\left[\mathrm{M}-\mathrm{H}-2\left(\mathrm{C}_{5} \mathrm{H}_{9}\right)\right]^{\prime}, \\
327.1952\left[\mathrm{M}-\mathrm{H}-\mathrm{C}_{7} \mathrm{H}_{5} \mathrm{O}-\mathrm{C}_{5} \mathrm{H}_{9}\right]^{-} \\
309.1128\left[\mathrm{M}-\mathrm{H}-\mathrm{C}_{7} \mathrm{H}_{5} \mathrm{O}-\mathrm{C}_{5} \mathrm{H}_{9}-\mathrm{H}_{2} \mathrm{O}\right]^{-}\end{array}$ \\
\hline 2 & 14.74 & $\begin{array}{l}\text { FL-1,FL-2, } \\
\text { FL3, AM }\end{array}$ & Xanthochymol & $\mathrm{C}_{38} \mathrm{H}_{50} \mathrm{O}_{6}$ & 601.3520 & 0.49 & $\begin{array}{c}465.3363\left[\mathrm{M}-\mathrm{H}-\mathrm{C}_{7} \mathrm{O}_{3} \mathrm{H}_{4}\right]^{-}, \\
449.1949\left[\mathrm{M}-\mathrm{H}-\mathrm{C}_{10} \mathrm{H}_{16} \mathrm{O}\right]- \\
177.1040\left[\mathrm{M}-\mathrm{H}-\mathrm{C}_{10} \mathrm{H}_{16} \mathrm{OC}_{15} \mathrm{H}_{12} \mathrm{O}_{5}\right]^{\prime}, \\
109.0288\left[\mathrm{C}_{6} \mathrm{O}_{2} \mathrm{H}_{5}\right]^{-}\end{array}$ \\
\hline 3 & 16.57 & $\begin{array}{l}\text { FL-1,FL-2, } \\
\text { FL3, AM }\end{array}$ & Guttiferone $\mathrm{C}$ or $\mathrm{D}$ & $\mathrm{C}_{43} \mathrm{H}_{58} \mathrm{O}_{6}$ & 669.4147 & 0.29 & $\begin{array}{c}533.3986\left[\mathrm{M}-\mathrm{H}-2\left(\mathrm{C}_{5} \mathrm{H}_{8}\right)\right]^{\prime}, \\
177.0185\left[\mathrm{M}-\mathrm{H}-\mathrm{C}_{10} \mathrm{H}_{16} \mathrm{O}-\mathrm{C}_{15} \mathrm{H}_{12} \mathrm{O}_{5}\right]^{\prime} \\
109.0295\left[\mathrm{C}_{6} \mathrm{H}_{5} \mathrm{O}\right]^{-}\end{array}$ \\
\hline 4 & 10.61 & FL-1, FL-2, FL-3 & Gambogenone & $\mathrm{C}_{27} \mathrm{H}_{32} \mathrm{O}_{6}$ & 451.2099 & 4.87 & $\begin{array}{c}315.1945\left[\mathrm{M}-\mathrm{H}-\mathrm{C}_{7} \mathrm{O}_{3} \mathrm{H}_{4}\right]^{-} \\
109.0279\left[\mathrm{C}_{6} \mathrm{O}_{2} \mathrm{H}_{2}\right]^{-}\end{array}$ \\
\hline 5 & 11.37 & $\begin{array}{l}\text { FL-1, FL-2, } \\
\text { FL-3, AM }\end{array}$ & Aristophenone A & $\mathrm{C}_{33} \mathrm{H}_{42} \mathrm{O}_{6}$ & 533.2898 & 3.37 & $464.2198\left[\mathrm{M}-\mathrm{H}-\mathrm{C}_{5} \mathrm{H}_{9}\right]^{-}$ \\
\hline 6 & 12.95 & $\begin{array}{l}\text { FL-1,FL-2, } \\
\text { FL3, AM }\end{array}$ & $\begin{array}{c}\text { Polyprenylated benzophenone } \\
\text { derivative }\end{array}$ & $\mathrm{C}_{33} \mathrm{H}_{42} \mathrm{O}_{4}$ & 501.3003 & $*$ & $\begin{array}{c}363.1597\left[\mathrm{M}-\mathrm{H}-2\left(\mathrm{C}_{5} \mathrm{H}_{9}\right)\right]^{-} \\
309.1127\left[\mathrm{M}-\mathrm{H}-\mathrm{C}_{7} \mathrm{H}_{5} \mathrm{O}-\mathrm{C}_{5} \mathrm{H}_{9}-\mathrm{H}_{2} \mathrm{O}\right]^{-}\end{array}$ \\
\hline 7 & 13,16 & $\begin{array}{l}\text { FL-1,FL-2, } \\
\text { FL3, AM }\end{array}$ & $\begin{array}{c}\text { (1R,5R,7R)-3-Benzoyl-7-[(2E)- } \\
\text { 3,7-dimethyl-2,6-octadien-1- } \\
\text { yl]-4-hydroxy-8,8-dimethyl- } \\
\text { 5-(3-methyl-2-buten-1-yl) } \\
\text { bicyclo[3.3.1]non-3-ene-2,9- } \\
\text { dione }\end{array}$ & $\mathrm{C}_{33} \mathrm{H}_{42} \mathrm{O}_{4}$ & 501.2998 & 0.59 & $\begin{array}{c}433,2365\left[\mathrm{M}-\mathrm{H}-\mathrm{C}_{5} \mathrm{H}_{9}\right]^{-} \\
336,1356\left[\mathrm{M}-\mathrm{H}-\mathrm{C}_{10} \mathrm{H} 17-\mathrm{C}_{2} \mathrm{H}_{5}\right]^{-} \\
309.1126\left[\mathrm{M}-\mathrm{H}-\mathrm{C}_{7} \mathrm{H}_{5} \mathrm{O}-\mathrm{C}_{5} \mathrm{H}_{9}-\mathrm{H}_{2} \mathrm{O}\right]^{-}\end{array}$ \\
\hline
\end{tabular}

*Dashes: unidentified compound. 
showed a deprotonated molecular ion at $\mathrm{m} / \mathrm{z} 501.3002[\mathrm{M}-\mathrm{H}]^{-}$, and a fragments at $\mathrm{m} / \mathrm{z}$ 432.2296, $\mathrm{m} / \mathrm{z}$ 417.2064, and $\mathrm{m} / \mathrm{z} 363.1586$ (Table 2), which is consistent with the presence of 7-epi-Nemorosone considering a $0.59 \mathrm{ppm}$ mass error. ${ }^{23}$ This ion was common to all samples from $F$. longipes and A. mellifera and was detected at similar retention times. In the samples FL-1, FL-2, FL-3, and AM, another benzophenones were detected by ESI-MS/MS. The signal at $m / z, 601.3520\left(\mathrm{C}_{38} \mathrm{O}_{6} \mathrm{H}_{49}\right)$ corresponds to a deprotonated molecular ion $[\mathrm{M}-\mathrm{H}]^{-}$, with a similar retention time (14.74 $\left.\mathrm{min}\right)$ and the same fragmentation pattern in all four samples, producing daughter ions at $\mathrm{m} / \mathrm{z}$ 465.3363, $\mathrm{m} / \mathrm{z}$ 449.1949, $\mathrm{m} / \mathrm{z}, 177.1040$, and $\mathrm{m} / \mathrm{z}, 109.0288$, which is consistent with the xanthochymol molecule considering a mass error of $0.49 \mathrm{ppm}$ (Table 2) ${ }^{23}$ The molecular ion [M-H] ${ }^{-}$at $\mathrm{m} / \mathrm{z}$, 669.4147 (16.57 $\mathrm{min}$ ) was tentatively identified as guttiferone $\mathrm{C}$ or $\mathrm{D}$ derivatives ${ }^{26}$ corresponding to the mass of the xanthochymol plus an isopentenyl unit $\left(\mathrm{C}_{5} \mathrm{H}_{8}, 68 \mathrm{Da}\right)$ showing the same fragmentation pattern, within a 0.29 ppm mass error (Table 2).

Other probable benzophenone was detected in FL-1, FL-2 and FL-3 samples (RT $10.61 \mathrm{~min}$ ) consistent with gambogenone, with deprotonated molecular ion at $\mathrm{m} / \mathrm{z} 451.2093[\mathrm{M}-\mathrm{H}]-\left(\mathrm{C}_{27} \mathrm{H}_{32} \mathrm{O}_{6}\right)$, producing daughter ions at $\mathrm{m} / \mathrm{z} 315.1945$ and $\mathrm{m} / \mathrm{z} 109.0279$, with mass error of $4.87 \mathrm{ppm} .23$ The peak at retention time $11.37 \mathrm{~min}$ present in all samples was tentatively characterized as aristophenone A, which produced a deprotonated ion $\mathrm{m} / \mathrm{z} 533.2898$ [M-H]$\left(\mathrm{C}_{33} \mathrm{O}_{6} \mathrm{H}_{41}\right)$ and a fragment at $\mathrm{m} / \mathrm{z} 464.2198$ (loss of the prenyl group), with mass error of $3.37 \mathrm{ppm} .23 \mathrm{In}$ addition, other probable polyprenylated benzophenones were are detected by LC-ESI-MS/ MS. These compounds showed a deprotonated molecular ion [M-H]- at m/z $501\left(\mathrm{C}_{33} \mathrm{H}_{42} \mathrm{O}_{4}\right)$, and in all cases, the fragmentation pattern showed ions at $\mathrm{m} / \mathrm{z} 309$, probably indicating the presence of a prenyl portion. The ion at $\mathrm{m} / \mathrm{z} 501.3003$ with RT $12.95 \mathrm{~min}$ (Table 2) yielded fragments at $\mathrm{m} / \mathrm{z} 363.1587$ and 309.1127. The compound at $\mathrm{m} / \mathrm{z} 501.2996$ with RT 13.16 min produced fragments at $\mathrm{m} / \mathrm{z} 433,2365\left[\mathrm{M}-\mathrm{H}-\mathrm{C}_{5} \mathrm{H}_{9}\right]-, 336,1356\left[\mathrm{M}-\mathrm{H}-\mathrm{C}_{10} \mathrm{H}_{17}-\mathrm{C}_{2} \mathrm{H}_{5}\right]-\mathrm{e}$ $309.1126\left[\mathrm{M}-\mathrm{H}-\mathrm{C}_{7} \mathrm{H}_{5} \mathrm{O}-\mathrm{C}_{5} \mathrm{H}_{9}-\mathrm{H}_{2} \mathrm{O}\right]-$ (Table 2) was tentatively characterized as (1R,5R,7R)-3-benzoyl-7-[(2E)-3,7-dimethyl-2,6octadien-1-yl]-4-hydroxy-8,8-dimethyl-5-(3-methyl-2-buten-1-yl) bicyclo[3.3.1]non-3-ene-2,9-dione. The fragmentation pattern of both compound showed the loss of $\mathrm{C}_{5} \mathrm{H}_{9}$ group, indicating the presence of a prenyl moiety. Polyprenylated benzophenones predominated in these samples making up a chemical profile very few reported for Brazilian propolis. The chromatograms of LC-ESI-MS/MS analysis and the mass spectra of the detected benzophenones are shown in Supplementary material (Figures 1S-8S).

\section{Determination of the antioxidant activity of the extracts}

The antioxidant activities of the propolis extracts were evaluated by different methods. The results of the analyses are listed in Table 3.

In the free radical DPPH sequestration method, the extract of
Table 3. Antioxidant activities of $F$. longipes and A. mellifera propolis extracts (mean $\pm \mathrm{SD} ; \mathrm{n}=3$ ).

\begin{tabular}{ccc}
\hline Propolis & $\begin{array}{c}\text { DPPH IC } \\
\left(\mu \mathrm{g} \mathrm{mL}^{-1}\right)\end{array}$ & $\begin{array}{c}\beta \text {-carotene/linoleic acid } \\
(\%)\end{array}$ \\
\hline FL-1 & $8.47 \pm 0.00040$ & $75.6 \pm 0.7$ \\
FL-2 & $8.64 \pm 0.00001$ & $75.1 \pm 1.1$ \\
FL-3 & $8.81 \pm 0.00002$ & $73.1 \pm 1.1$ \\
AM & $3.74 \pm 0.00020$ & $75.5 \pm 1.1$ \\
BHT & $6.00 \pm 0.00020$ & $86.4 \pm 0.7$ \\
\hline
\end{tabular}

the propolis from A. mellifera presented high antiradical action, with values above those for the propolis of $F$. longipes. Using the $\beta$-carotene/linoleic acid oxidation method, both the propolis of $A$. mellifera and $F$. longipes exhibited strong protection capacity of a lipid substrate, presenting comparable percentages to that of the reference standard, BHT. Mendonça et al..$^{26}$ in a study on red propolis of A. mellifera determined the $\mathrm{IC}_{50}$ using the radical DPPH sequestration method for several extracts among which the ethanolic extract presented a value of $8.01 \mu \mathrm{g} \mathrm{mL} \mathrm{m}^{-1}$, similar to those found for F. longipes. Campos et al..$^{28}$ evaluated the biological activities of Melipona orbignyi propolis and obtained an $\mathrm{IC}_{50}$ of $40.0 \mu \mathrm{g} \mathrm{mL} \mathrm{L}^{-1}$, a much greater value than those for the samples from $F$. longipes and A. mellifera. Propolis has been reported to be a source of compounds with phenolic functionalities. Consequently, its antioxidant activities have been intensely investigated because phenolic substances are recognized as potent antioxidants. The antioxidant activity of phenolic compounds is related to their structural arrangements, which promote the inactivation of free radicals through the donation of hydrogen atoms or in the complexation of metals, which occurs due to the presence of hydroxyl groups, conjugated double bonds, and carbonyl groups. ${ }^{29,30}$

The results obtained in this study can be attributed to the presence of prenylated benzophenones, and the antioxidant activities of 7-epinemorosone, xanthochymol, gambogenone and aristophenone A identified in this study have already been determined. ${ }^{31,32}$ Trusheva et $a l .{ }^{32}$ have isolated several compounds with high antioxidant activities, among them prenylated benzophenones, from red propolis. The data obtained in the present study show the potential antioxidant properties of propolis by two separate methods used to measure antioxidant activity.

\section{Antimicrobial activities of the extracts}

Table 4 shows the results regarding the antimicrobial activities of ethanolic propolis extracts. All extracts are active against all microorganisms used.

There is currently no antimicrobial activity data for F. longipes propolis in the literature. The sample FL-3 exhibited activity against B. cereus (ATCC 11778) that is comparable to that of

Table 4. Antimicrobial activities of $F$. longipes and A. mellifera propolis extracts.

\begin{tabular}{|c|c|c|c|c|c|c|}
\hline & B. cereus & E. coli & S. aureus & P. aeruginosa & C. albicans & C. tropicalis \\
\hline & \multicolumn{6}{|c|}{$\mathrm{CIM}\left(\mu \mathrm{g} \mathrm{mL} \mathrm{L}^{-1}\right)$} \\
\hline FL-1 & 15.6 & 125 & 125 & 31.3 & 62.5 & 250 \\
\hline FL-2 & 15.6 & 125 & 125 & 62.5 & 62.5 & 250 \\
\hline FL-3 & 7.8 & 125 & 125 & 62.5 & 250 & 250 \\
\hline $\mathrm{AM}$ & 62.5 & 62.5 & 125 & 31.3 & 250 & 500 \\
\hline Ampicillin & 7.8 & 7.8 & 15.6 & 62.5 & - & - \\
\hline Fluconazole & - & - & - & - & 31.3 & 12.5 \\
\hline
\end{tabular}


ampicillin. A. mellifera (AM) showed the highest activity against E. coli (ATCC 13863) of all the samples. S. aureus (ATCC 43300) is resistant to methicillin and oxacillin but was inhibited by all the extracts tested. All extracts exhibited strong antimicrobial activity for all microorganisms and new studies must be carried out to determine active compounds. ${ }^{33}$

\section{CONCLUSIONS}

The study revealed that the volatile compositions of propolis were very different between the two different bee species examined, as $F$. longipes propolis contained both mono- and sesquiterpenes, whereas the propolis of A. mellifera contained only sesquiterpenes. The chemical profiles of the extracts showed a greater diversity of ionizable compounds in the samples of the stingless bee, and although the colonies sampled were found in the same environment, the individual samples had several constituents that were unique to a particular sample. The antioxidant and antimicrobial activities of the extracts were significant, and could be better explained upon the determination of the biological activities of isolated constituent compounds in future studies.

\section{ACKNOWLEDGEMENT}

The authors are grateful for the financial support provided by the Conselho Nacional de Desenvolvimento Científico e Tecnológico, Brazil (Proc. 472917/2011-0) and to the Coordenação de Aperfeiçoamento de Pessoal de Nível Superior for granting a scholarship (Edineide Cristina Alexandre de Souza) the and finantial suport (CAPES - PRÓ-AMAZÔNIA - Auxílio 3260/2013).

\section{SUPPLEMENTARY MATERIAL}

Figures $1 \mathrm{~S}$ to $8 \mathrm{~S}$ are available for free download at http:// quimicanova. sbq.org.br in pdf format.

\section{REFERENCES}

1. Viuda-Martos, M.; Ruiz-Navajas, Y.; Fernández-López, J; Pérez-Álvarez, J. A.; J Food Sci. 2008, 73, R117.

2. Miguel, M. G.; Antunes, M. D.; J Pharm Bioallied Sci. 2011, 3, 479.

3. Huang, S.; Zhang, C.; Wang, K.; Li, G.Q.; Hu, F. L.; Molecules. 2014, $19,19610$.

4. Simone-Finstrom, M.; Spivak, M.; Apidologie 2010, 41, 295.

5. Salatino, A.; Teixeira, E. W.; Negri, G.; Message, D.; Evid Based Complement Alternat Med. 2005, 2, 33.

6. Silva, B. B.; Rosalen, P. L.; Cury, J. A.; Ikegaki, M.; Souza, V. C.; Esteves, A.; Alencar S.M.; Evid Based Complement Alternat Med. 2008 , 5,313 .

7. Cortopassi-Laurino, M.; Imperatriz-Fonseca, V. L.; Roubik, D. W.; Dollin, A.; Heard, T.; Aguilar, I.; Venturieri, G. C.; Eardley, C.; Nogueira-Neto, P.; Apidologie 2006, 37, 275.

8. Fernandes Jr., A.; Leomil, L.; Fernandes, A. A. H.; Sforcin, J. M.; J. of Venomous Anim. Toxins 2001, 7, 173.
9. Pino, J. A.; Marbot, R.; Delgado, A.; Zumárraga, C.; Sauri, E.; J. Essent. Oil Res. 2006, 18, 53.

10. Farnesi, A. P.; Aquino-Ferreira, R.; De Jong, D.; Bastos, J. K.; Soares, A. E.; Genet Mol Res. 2009, 8, 635.

11. Liberio, A. S.; Pereira, A. L. A.; Dutra, R. P.; Reis, A. S.; Araújo, M. J. A. M.; Mattar, N. S.; Silva, L. A.; Ribeiro, M. N. S.; Nascimento, F. R. F.; Guerra, R. N. M.; Monteiro-Neto, V.; BMC Complementary Altern. Med. 2011, 11, 108.

12. Bankova, V. S.; Christov, R.; Popov, S.; Marcucci, M. C.; Tsvetkova, I.; Kujumgiev, A.; Fitoterapia 1999, 70, 190.

13. Bankova, V.; Popova, M.; Trusheva, B.; Chem. Cent. J. 2014, 8, 28.

14. Van Den Dool, H.; Kratz, P. D. A.; J. Chromatogr. 1963, 2, 463.

15. Adams, R.P.; Identification of Essential Oil Components by Gas chromatography/quadrupole Mass Spectroscopy. $4^{\text {rd }}$ ed., Publisher: Allured Publishing Corporation, 2007, pp.15-804.

16. Mensor, L. L.; Menezes, F. S.; Leitão, G. G.; Reis, A. S.; Santos, T. C.; Coube, C. S.; Leitão, S. G.; Phytother. Res. 2001, 15, 127.

17. Emmons, C. L.; Peterson, D. M.; Paul, G. L.; J. Agric. Food Chem. 1999, 47, 4894.

18. Clinical and Laboratory Standards Institute. Methods for Dilution Antimicrobial Susceptibility Tests for Bacteria That Grow Aerobically; Approved Standard-Ninth Edition. CLSI document M07-A9. Wayne, PA: CLSI; 2012.

19. Patricio, E. F. L. R. A.; Cruz-López, L.; Maile, R.; Morgan, E. D.; Apidologie 2003, 34, 359

20. Leonhardt, S. D.; Bluthgen, N.; Biotropica 2009, 41, 730.

21. Leonhardt, S. D.; Schmitt, T.; Bluthgen, N.; PLoS One 2011; 6, 23445.

22. Leonhardt, S. D.; Zeilhofer, S.; Bluthgen, N.; Schmitt, T.; Chem. Senses. 2010, 35, 603 .

23. Ishida, V. F. C.; Negri, G.; Salatino, A.; Bandeira, M. F. C. L.; Food Chem. 2011, 12, 966.

24. Chattopadhyay, S. K.; Kumar, S.; J Chromatogr. B. 2006, 844, 67.

25. Kumar, S.; Chattopadhyay, S. K.; Biomed. Chromatogr. 2007, 21, 139.

26. Mendonça, I. C. G.; Porto, I. C. C. M.; Nascimento, T. G.; Souza, N. S.; Oliveira, J. M. S.; Arruda, R. E. S.; Mousinho, K. C.; dos Santos, A. F.: Basílio-Júnior, I. D.; Parolia, A.; Barreto F. S.; BMC Complement Altern. Med. 2015, 15, 357.

27. Tomás-Barberán, F. A.; Garcia-Viguera, C.; Vit-Olivier, P.; Ferreres, F.; Tomas-Lorente, F.; Phytochemistry 1993, 34, 191.

28. Campos, J.F.; Santos, U.P.; Rocha, P.S.; Damião, M.J.; Balestieri, J.B.P.; Cardoso, C.A.L.; Paredes-Gamero, E. J.; Estevinho, L. M.; Souza, K. de Picolo; dos Santos, E. L.; Evid Based Complement Alternat Med. 2015; Article ID 296186, 1.

29. Cook, N.; Samman, S. J. Nutr. Biochem. 1996, 7, 66.

30. Silva, J. F. M.; Souza, M. C.; Matta, S. R.; Andrade, M. R.; Vidal, F. V. N.; Food Chem. 2006, 99, 431.

31. Piccinelli, A. L.; Cuesta-Rubio, O.; Chica, M. B.; Mahmood, N.; Pagano, B.; Pavone, M.; Barone, V.; Rastrelli, L.; Tetrahedron 2005, 61, 8206.

32. Baggett, S.; Protiva, P.; Mazzola, E. P.; Yang, H.; Ressler, E. T.; Basile, M. J.; Weinstein, B.; Kennelly, E. J.; J. Nat. Prod. 2005, 68, 354.

33. Duarte, M. C. T; Leme, E. E.; Delarmelina, C.; Soares, A. A.; Figueira, G. M.; Sartoratto, A.; J. Ethnopharmal. 2007, 111, 197. 